\title{
BMI open Pulmonary arterial hypertension associated with connective tissue disease: meta-analysis of clinical trials
}

\author{
Masataka Kuwana, ${ }^{1}$ Hiroshi Watanabe, ${ }^{2}$ Nobushige Matsuoka, ${ }^{3}$ \\ Naonobu Sugiyama ${ }^{4}$
}

To cite: Kuwana M, Watanabe $\mathrm{H}$, Matsuoka N, et al. Pulmonary arterial hypertension associated with connective tissue disease: meta-analysis of clinical trials. BMJ Open 2013;3 e003113. doi:10.1136/ bmjopen-2013-003113

- Prepublication history and additional material for this paper is available online. To view these files please visit the journal online (http://dx.doi.org/10.1136/ bmjopen-2013-003113)

Received 24 April 2013 Revised 10 June 2013 Accepted 27 June 2013

${ }^{1}$ Division of Rheumatology, Department of Internal Medicine, Keio University School of Medicine, Tokyo, Japan

${ }^{2}$ Department of Clinical Pharmacology and Therapeutics, Hamamatsu University School of Medicine, Shizuoka, Japan ${ }^{3}$ Division of Clinical Statistics, Pfizer Japan Inc., Tokyo, Japan

${ }^{4}$ Division of Medical Affairs, Pfizer Japan Inc., Tokyo, Japan

Correspondence to Dr Masataka Kuwana; kuwanam@z5.keio.jp

\section{ABSTRACT}

Objectives: Few studies have focused on pulmonary arterial hypertension (PAH) associated with connective tissue diseases (CTDs). The optimal treatment for CTD$\mathrm{PAH}$ has yet to be established.

Design: Meta-analysis of the data from evaluations of treatment for PAH generally (19 studies) and CTD-PAH specifically (nine studies) to compare the effects of pulmonary vasodilative PAH agents. MEDLINE, EMBASE and BIOSIS were searched. English-language full-text articles published between January 1990 and August 2012 were eligible.

Setting: International.

Participants: Patients with PAH generally $(\mathrm{n}=3073)$ and CTD-PAH specifically $(\mathrm{n}=678)$.

Primary outcome measure: Exercise capacity (6 min walk distance, $6 \mathrm{MWD}$ ).

Results: Patients with PAH (all forms) had mean age 32-55 years (women, 61-87\%); CTD-PAH patients had mean age $45-55$ years (women, $74-95 \%$ ). Overall estimate of mean change in 6 MWD from baseline $(95 \% \mathrm{Cl})$ for the active treatment group versus the control group in all patients with PAH was $34.6 \mathrm{~m}$ (27.4-41.9 m). Pooled mean differences from the results for patients receiving placebo by subgroup of patients receiving phosphodiesterase (PDE)-5 inhibitors, endothelin receptor antagonists (ERAs) and prostacyclin $\left(\mathrm{PGI}_{2}\right)$ analogues were 22.4-45.5, $39.5-44.2$ and $12.4-64.9 \mathrm{~m}$, respectively. Overall estimate of mean difference between changes in $6 \mathrm{MWD}$ in patients with CTD-PAH was $34.2 \mathrm{~m}$ (23.3-45.0 m). Pooled mean differences by subgroup of patients receiving PDE-5 inhibitors, ERAs and $\mathrm{PGI}_{2}$ analogues in patients with CTD-PAH were $37.0-47.1,14.1-21.7$ and $21.0-108.0 \mathrm{~m}$, respectively. ERAs were less effective in patients with CTD-PAH than all-form patients with PAH: $14.1 \mathrm{~m}(-4.4-32.6 \mathrm{~m})$ vs $39.5 \mathrm{~m}(19.5-59.6 \mathrm{~m})$ for bosentan and $21.7 \mathrm{~m}$ $(2.2-41.3 \mathrm{~m})$ vs $44.2 \mathrm{~m}(30.2-58.2 \mathrm{~m})$ for ambrisentan.

Conclusions: All three types of PAH agent are effective. However, ERAs may be a less effective choice against CTD-PAH; further studies are needed. Limitations include the limited number of studies for some agents and for patients with CTD-PAH.

\section{ARTICLE SUMMARY}

Article focus

- Pulmonary arterial hypertension (PAH) is a progressive disease characterised by abnormally high blood pressure in the pulmonary arteries.

- Patients with PAH associated with connective tissue diseases (CTDs) such as systemic sclerosis (SSc) have a particularly poor prognosis.

- Few studies have focused on patients with CTD-PAH, so the optimal treatment for these patients is unclear.

\section{Key messages}

- The effects of the phosphodiesterase- 5 inhibitors sildenafil and tadalafil, and the prostacyclin analogue epoprostenol, are consistent in patients with CTD-PAH and in those with PAH generally.

- The endothelin receptor antagonists bosentan and ambrisentan may be less effective in patients with CTD-PAH than in those with PAH generally.

Strengths and limitations of this study

- The meta-analysis used all currently available data from clinical studies on treatment for PAH.

- Few studies were identified for some PAH agents and for patients with CTD-PAH.

- Study designs and patient background characteristics, including the percentages of patients with SSc-PAH, were inconsistent between studies.

\section{INTRODUCTION}

Pulmonary hypertension is a heterogeneous condition with sustained elevation of pressure in the pulmonary arteries, and is defined as mean pulmonary artery pressure $\geq 25 \mathrm{~mm} \mathrm{Hg}$ at rest. ${ }^{1}$ The most recent and widely accepted clinical classification of pulmonary hypertension is that proposed at the Fourth World Symposium on Pulmonary Hypertension at Dana Point in $2008 .^{2}$ It classifies pulmonary hypertension into five groups. Group 1 comprises pulmonary arterial hypertension $(\mathrm{PAH})$, which includes idiopathic $\mathrm{PAH}$, heritable $\mathrm{PAH}$, drug-induced and toxin-induced $\mathrm{PAH}, \mathrm{PAH}$ associated with 
various diseases and persistent pulmonary hypertension of the newborn. Group 2 comprises pulmonary hypertension owing to left heart disease; group 3, pulmonary hypertension owing to lung diseases and/or hypoxia; group 4, chronic thromboembolic pulmonary hypertension; and group 5, pulmonary hypertension of unknown cause. In this classification of pulmonary hypertension, $\mathrm{PAH}$ is recognised as having an extremely poor prognosis and requires specific medical treatment.

Connective tissue disease (CTD) is the most common condition associated with PAH. Recent cohort studies have shown that most patients with PAH associated with CTD have systemic sclerosis (SSc). ${ }^{3}{ }^{4}$ In fact, the prevalence of PAH in patients with SSc is reported to be 7-12\%..$^{5}$ Patients with SSc-PAH have poor prognosis compared with patients with idiopathic PAH. ${ }^{7}$ Therefore, early and appropriate diagnosis and selection of the optimal treatment regimen are important for SSc-PAH, to improve the hemodynamics, exercise capacity and eventually survival of patients.

The optimal treatment for PAH has not been established. However, there has been major progress in medical treatment for PAH in recent years. Several new agents with different mechanisms have been introduced, including phosphodiesterase (PDE)-5 inhibitors (eg, oral sildenafil and tadalafil), endothelin receptor antagonists (ERAs) (eg, oral bosentan and ambrisentan) and prostacyclin $\left(\mathrm{PGI}_{2}\right)$ analogues (eg, continuous intravenous epoprostenol). The introduction of these new agents is expected to contribute to the improvement of exercise capacity, subjective symptoms and quality of life, as well as the short-term and long-term survival of patients.

Although the efficacy and safety of these new agents have been shown in small-scale or medium-scale randomised controlled trials (RCTs) and open-label trials, evidence from large-scale comparative studies of these agents remains insufficient because PAH is a rare disease. Therefore, to compare the new agents and establish a therapeutic strategy for PAH, several systematic reviews and meta-analyses of available clinical study results have been done. ${ }^{8-13}$ However, most of these analyses include studies on all forms of PAH, and studies that focus on CTD-PAH are limited. In fact, our literature search showed only one such report: a metaanalysis by Avouac et $a l^{8}$ which investigated the efficacy of oral PAH agents mainly in patients with SSc.

Therefore, in this meta-analysis of studies designed as RCTs and open-label, single-arm trials, we aimed to evaluate the effect of each PAH agent on exercise capacity in patients with CTD-PAH compared with patients with all forms of PAH. We chose 6 min walk distance (6 MWD) as an endpoint because it was used as a primary endpoint in most previous randomised studies of PAH agents. ${ }^{14}$

\section{METHODS}

\section{Eligibility criteria}

To evaluate the effects of three typical types of PAH agent, we included RCTs in which the following PAH agents were administered to patients with all forms of PAH.

- PDE-5 inhibitors: sildenafil and tadalafil

- ERAs: bosentan and ambrisentan

- $\mathrm{PGI}_{2}$ analogues: epoprostenol, beraprost, iloprost and treprostinil.

Because the number of RCTs in patients with CTD-PAH is limited, we also included open-label, singlearm trials evaluating the effects of $\mathrm{PAH}$ agents in patients with CTD-PAH.

We excluded reviews and non-interventional studies (eg, case reports and observational studies as opposed to RCTs). We included only principal studies and excluded ad hoc analyses. Studies in which results for 6 MWD were not reported were also excluded, as were studies on pulmonary hypertension other than PAH.

\section{Search strategy}

We searched MEDLINE, EMBASE and BIOSIS for English-language full-text articles published between January 1990 and August 2012, using the key terms 'pulmonary arterial hypertension', ' 6 min walk' and the names of individual drugs. In addition to these key terms, we used the term 'randomised controlled trial' or 'RCT' to identify RCTs evaluating all forms of PAH, and 'connective tissue disease' or 'CTD' to identify studies evaluating CTD-PAH. The last search was run on 5 December 2012. Additional studies were identified through manual searching.

\section{Primary endpoint}

The primary outcome measure was the difference in mean change from baseline in 6 MWD between groups. However, for single-arm studies, the mean change from baseline was used as the primary outcome measure.

\section{Data collection}

Relevant data were extracted and reviewed by NM and NS. Data on study characteristics (year and design), variables including PAH agents used, total patient numbers and the percentage of patients with CTD-PAH and outcomes (mean difference, $\mathrm{m}$ and $95 \% \mathrm{CI}, \mathrm{m}$ or $\mathrm{SE}$ ) were extracted.

\section{Risk of bias}

To determine the validity of the included studies, we assessed the risk of bias for each study in terms of random sequence generation, allocation concealment, blinding and other sources of bias, as recommended by the Cochrane Collaboration. Each domain was judged to have high, low or unclear risk of bias. We did not detect clear publication bias, because the number of included studies was small.

\section{Statistical analysis}

We pooled outcomes by each PAH agent for all forms of PAH and for CTD-PAH. We used a random effects model based on the DerSimonian-Laird method 
because of known clinical and methodological heterogeneity (eg, the various doses of each PAH agent). The $\mathrm{I}^{2}$ values were calculated as a measure of heterogeneity. The $\mathrm{I}^{2}$ statistic, which describes the percentage of variability in effect estimates that is due to heterogeneity rather than sampling error (chance), and we considered $\mathrm{I}^{2}>75 \%$ as representing considerable heterogeneity.

\section{RESULTS}

\section{Selection of studies}

A total of 196 articles were identified for evaluation of treatments for all forms of PAH. Of these, 19 articles (reporting data from 3073 patients) met the eligibility criteria for evaluations of treatments for all forms of PAH (3 articles for sildenafil, ${ }^{15-17} 1$ article for tadalafil, ${ }^{18}$ 4 articles for bosentan, ${ }^{19-22} 1$ article for ambrisentan, ${ }^{23}$ 3 articles for epoprostenol, ${ }^{24-26} 1$ article for beraprost, ${ }^{27}$ 2 articles for iloprost ${ }^{28} 29$ and 4 articles for treprostinil ${ }^{30-33}$; figure 1A). The main reasons for exclusion were that the article was a review and that the article reported the results of a study that involved patients other than those with PAH.

For evaluation of treatments for CTD-PAH, a total of 269 articles were identified. Of these, nine articles (reporting data from 678 patients) met the eligibility criteria for evaluations of treatments for CTD-PAH (1 article for sildenafil, ${ }^{34} 1$ article for tadalafil, ${ }^{18} 2$ articles for bosentan, ${ }^{35} 362$ articles for ambrisentan, ${ }^{37} 381$ article for epoprostenol, ${ }^{26} 1$ article for beraprost ${ }^{39}$ and 1 article for treprostinil ${ }^{40}$; figure $1 \mathrm{~B}$ ). The main reasons for exclusion were that the article was a review and that the article reported the results of a study that involved patients other than those with CTD-PAH.

\section{Characteristics and overview of the included studies}

Of the 19 studies on treatments for all forms of PAH included in this analysis (table 1), 15 were randomised, placebo-controlled, double-blind studies ${ }^{15-23} \quad 27 \quad 28$ 30-33; 3 were randomised, open-label studies comparing with conventional treatment ${ }^{24-26}$; and 1 was a randomised, open-label study evaluating the effects of iloprost when added to bosentan. ${ }^{29}$ The observation period was either 12 or 16 weeks in most of the studies, with some exceptions (one study each with 6-week and 24-week observation periods ${ }^{16}{ }^{22}$ and two studies with an 8-week observation period ${ }^{24}{ }^{31}$ ). Of the placebo-controlled randomised comparative studies, one study of sildenafil was performed in patients previously treated with epoprostenol $^{17}$; two studies of iloprost, in patients previously treated with bosentan ${ }^{28} 29$; and one study of treprostinil, in patients previously treated with bosentan or sildenafil. $^{32}$

Of the nine studies on treatments for CTD-PAH included in this analysis (table 2), five were placebocontrolled, double-blind studies, ${ }^{18} 34353740$ one was a randomised, open-label study comparing with conventional treatment ${ }^{26}$ and three were open-label, single-arm studies. ${ }^{36} 3839$ The observation period in these studies was 8-28 weeks. One study each evaluating bosentan ${ }^{36}$ and epoprostenol ${ }^{26}$ included only patients with SSc-PAH.

\section{Background of all patients with PAH}

The background of all patients with $\mathrm{PAH}$, based on data from the 19 studies, can be summarised as follows (full data in online supplementary table S1). Mean age was $32-55$ years, and the percentage of women was $61-87 \%$. In the studies of sildenafil, ${ }^{15-17}$ tadalafil, ${ }^{18}$ bosentan, ${ }^{19-22}$ ambrisentan $^{23}$ and beraprost, ${ }^{27}$ most patients were classified according to WHO functional class (WHO-FC) as in WHO-FC II or III, with one study including only patients in WHO-FC II. ${ }^{22}$ In contrast, in the studies of epoprostenol, ${ }^{24-26}$ the percentage of patients in WHO-FC IV was higher than that in studies of other agents. In the studies of iloprost, most patients were in WHO-FC III. ${ }^{28}{ }^{29}$ In the studies of treprostinil, most patients were in WHO-FC III in three studies ${ }^{30} 3233$ and in WHO-FC II in one study. ${ }^{31}$ Baseline $6 \mathrm{MWD}$ was $226.6-434.5 \mathrm{~m}$, and it was lower in the three studies of epoprostenol (226.6, 294.3 and $255.9 \mathrm{~m})^{24-26}$ compared with in studies on other agents. Therefore, patients with more severe disease were included in the studies of epoprostenol than in other studies. One study of bosentan included only patients with Eisenmenger syndrome. ${ }^{21}$

\section{Background of the subgroup of patients with CTD-PAH}

The background of patients with CTD-PAH, using data from nine studies, can be summarised as follows (full data in online supplementary table S2). Mean age was $45-55$ years, and the percentage of women was $74-95 \%$. In one study of tadalafil, there was no information on baseline 6 MWD or WHO-FC. ${ }^{18}$ As for the distribution of patients according to WHO-FC, a study of beraprost included more patients in WHO-FC II, ${ }^{39}$ and a study of epoprostenol included more patients in WHO-FC $\mathrm{IV}^{26}$ compared with studies of other agents.

In five studies in which information on underlying CTDs was available, patients with SSc-PAH accounted for $45-100 \%$ of all patients included. Their mean age was $51-55$ years, and the percentage of women was $74-90 \%$.

In studies of bosentan ${ }^{36}$ and epoprostenol ${ }^{26}$ that included only patients with SSc-PAH, baseline $6 \mathrm{MWD}$ was $<300 \mathrm{~m}$, which was lower than that in studies of other agents. Therefore, the study of beraprost included more patients with relatively mild $\mathrm{PAH}$, whereas the study of epoprostenol included more patients with more severe disease.

\section{Results of 6 MWD}

The actual values of the outcomes for each study are presented on the right side of figures 2 and 3 . We pooled the data, including those for non-approved doses, to evaluate the effect of each PAH agent on exercise capacity in patients with CTD-PAH compared with in patients with all forms of PAH. 
(A)

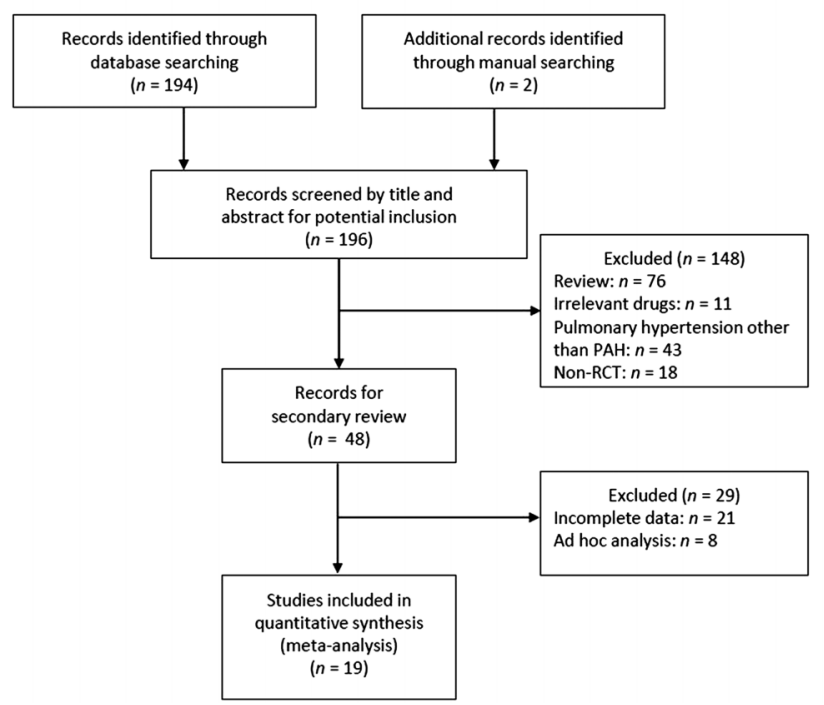

(B)

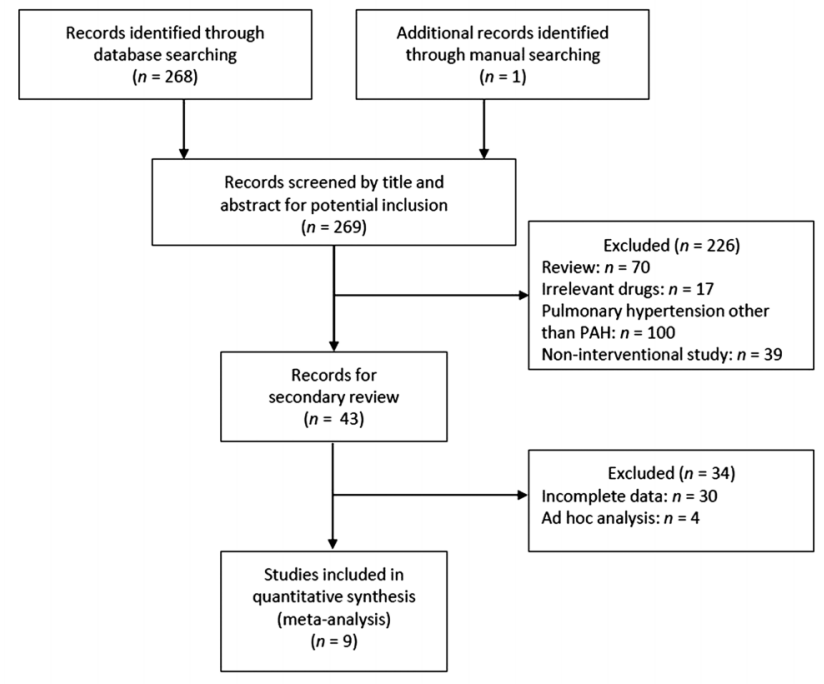

Figure 1 Flow diagram summarising selection of studies evaluating treatments for patients with (A) all forms of pulmonary arterial hypertension (PAH) and (B) connective tissue disease-PAH. RCT, randomised controlled trial.

\section{MWD in all patients with PAH}

The mean differences between changes in 6 MWD compared with the control group are shown in figure 2 by each agent. With a random effects model, the pooled mean difference between changes in 6 MWD was $45.5 \mathrm{~m}$ (95\% CI 32.9 to $\left.58.1 \mathrm{~m}, \mathrm{I}^{2}=50.1 \%\right)$ for sildenafil, $22.4 \mathrm{~m}(95 \% \mathrm{CI}$ 14.0 to $\left.30.9 \mathrm{~m}, \mathrm{I}^{2}=7.9 \%\right)$ for tadalafil, $39.5 \mathrm{~m}$ (95\%CI 19.5 to $\left.59.6 \mathrm{~m}, \mathrm{I}^{2}=38.3 \%\right)$ for bosentan, $44.2 \mathrm{~m}(95 \%$ CI 30.2 to $\left.58.2 \mathrm{~m}, \mathrm{I}^{2}=0 \%\right)$ for ambrisentan, $64.9 \mathrm{~m}$ (95\% CI 20.4 to $\left.109.4 \mathrm{~m}, \mathrm{I}^{2}=43.3 \%\right)$ for epoprostenol, $25.1 \mathrm{~m}$ (95\%CI 1.9 to $48.4 \mathrm{~m}, \mathrm{I}^{2}=$ not applicable (NA)) for beraprost, $12.4 \mathrm{~m}$ $\left(95 \% \mathrm{CI}-21.9\right.$ to $\left.46.6 \mathrm{~m}, \mathrm{I}^{2}=39.7 \%\right)$ for iloprost, and $17.3 \mathrm{~m}$ (95\% CI 6.1 to $28.4 \mathrm{~m}, \mathrm{I}^{2}=29.4 \%$ ) for treprostinil. Numerical improvement in 6 MWD was obtained in patients using each agent compared with those using the control agent. The pooled mean difference between changes in 6 MWD from the control group ranged from 12.4 to $64.9 \mathrm{~m}$, and the overall estimate of mean difference was $34.6 \mathrm{~m}\left(95 \%\right.$ CI 27.4 to $\left.41.9 \mathrm{~m}, \mathrm{I}^{2}=63.2 \%\right)$. The ranges of mean difference from the effects of placebo by subgroup of patients receiving PDE-5 inhibitors, ERAs and $\mathrm{PGI}_{2}$ analogues were 22.4-45.5, 39.5-44.2 and 12.4-64.9 m, respectively. Considerable heterogeneity was not observed.

\section{MWD in a subgroup of patients with CTD-PAH}

In the subgroup of patients with CTD-PAH, the mean differences between changes in 6 MWD compared with the control group are shown in figure 3 by each agent. For single-arm studies, the mean changes from baseline are shown. With a random effects model, the pooled mean difference between changes in $6 \mathrm{MWD}$ was $47.1 \mathrm{~m}(95 \%$ CI 27.9 to $\left.66.3 \mathrm{~m}, \mathrm{I}^{2}=0 \%\right)$ for sildenafil, $37.0 \mathrm{~m}(95 \%$ CI 19.0 to $\left.55.0 \mathrm{~m}, \mathrm{I}^{2}=0 \%\right)$ for tadalafil, $14.1 \mathrm{~m} \mathrm{(95 \%} \mathrm{CI}-4.4$ to $\left.32.6 \mathrm{~m}, \mathrm{I}^{2}=0 \%\right)$ for bosentan, $21.7 \mathrm{~m}(95 \%$ CI 2.2 to $\left.41.3 \mathrm{~m}, \mathrm{I}^{2}=0 \%\right)$ for ambrisentan, $108.0 \mathrm{~m}(95 \%$ CI 45.6 to $\left.170.4 \mathrm{~m}, \mathrm{I}^{2}=\mathrm{NA}\right)$ for epoprostenol, $58.5 \mathrm{~m}$ (95\% CI 21.4 to $\left.95.6 \mathrm{~m}, \mathrm{I}^{2}=\mathrm{NA}\right)$ for beraprost and $21.0 \mathrm{~m}(95 \% \mathrm{CI}-6.9$ to $48.9 \mathrm{~m}, \mathrm{I}^{2}=\mathrm{NA}$ ) for treprostinil. Numerical improvement in 6 MWD was obtained in patients using all agents compared with those using the control agent. The overall estimate of mean difference between changes in $6 \mathrm{MWD}$ in patients with CTD-PAH was $34.2 \mathrm{~m}$ (95\% CI 23.3 to $\left.45.0 \mathrm{~m}, \mathrm{I}^{2}=32.5 \%\right)$. The ranges of mean differences by subgroup of patients receiving PDE-5 inhibitors, ERAs and $\mathrm{PGI}_{2}$ analogues were 37.0-47.1, 14.1-21.7 and 21.0$108.0 \mathrm{~m}$, respectively. Considerable heterogeneity was not observed.

We did an additional sensitivity analysis excluding open-label single-arm studies for patients with CTD-PAH only (see online supplementary figure). The overall estimate of mean difference between changes in 6 MWD in patients with CTD-PAH was $37.2 \mathrm{~m} \quad(95 \% \mathrm{CI} 25.0$ to $\left.49.3 \mathrm{~m}, \mathrm{I}^{2}=20.5 \%\right)$ and the ranges of mean differences by subgroup of patients receiving PDE-5 inhibitors, ERAs and $\mathrm{PGI}_{2}$ analogues were $37.0-47.1,19.0-22.1$ and 21.0 $-108.0 \mathrm{~m}$, respectively.

\section{Difference in exercise capacity between all patients with PAH and CTD-PAH}

When the pooled mean differences between changes in 6 MWD were compared between all patients with $\mathrm{PAH}$ and each subgroup of patients with CTD-PAH, no difference in exercise capacity was found between the patient groups for PDE-5 inhibitors (sildenafil and tadalafil). In contrast, for ERAs (bosentan and ambrisentan), the pooled mean values in patients with CTD-PAH (bosen$\tan , 14.1 \mathrm{~m}$; ambrisentan, $21.7 \mathrm{~m}$ ) were lower than the lower limit of $95 \% \mathrm{CI}$ of the mean values in all patients with PAH (bosentan 19.5-59.6 m; ambrisentan 30.2$58.2 \mathrm{~m}$ ), suggesting that effects on exercise capacity may vary between patient groups. For $\mathrm{PGI}_{2}$ (epoprostenol, 
Table 1 Summary of included studies evaluating treatment with PAH agents in patients with all forms of PAH

\begin{tabular}{|c|c|c|c|c|c|c|c|c|}
\hline $\begin{array}{l}\text { Source (official } \\
\text { acronym) }\end{array}$ & PAH agent & $\begin{array}{l}\text { Number of } \\
\text { patients }\end{array}$ & $\begin{array}{l}\text { Number (\%) } \\
\text { of CTD-PAH } \\
\text { patients }\end{array}$ & $\begin{array}{l}\text { Study } \\
\text { design }\end{array}$ & Intervention & Control & $\begin{array}{l}\text { Period } \\
\text { (weeks) }\end{array}$ & $\begin{array}{l}\text { Results for } \\
\text { CTD-PAH }\end{array}$ \\
\hline $\begin{array}{l}\text { Galiè et al }{ }^{15} \\
\text { (SUPER-1) }\end{array}$ & Sildenafil & 278 & $84(30)$ & $\mathrm{RCT}, \mathrm{DB}$ & $\begin{array}{l}20 \mathrm{mg} \times 3 / \text { day, } 40 \mathrm{mg} \times 3 / \text { day and } \\
80 \mathrm{mg} \times 3 / \text { day }\end{array}$ & Placebo & 12 & $\begin{array}{l}\text { Available in } \\
\text { Badesch } \\
\text { et } a l^{\beta 4}\end{array}$ \\
\hline Singh et $a l^{16}$ & Sildenafil & 20 & 0 & $\mathrm{RCT}, \mathrm{DB}$ & $\begin{array}{l}25 \mathrm{mg} \text { on first day, then if no } \\
\text { hypotension, } 100 \mathrm{mg} \times 3 / \text { day }\end{array}$ & Placebo & 6 & None \\
\hline $\begin{array}{l}\text { Simonneau } \\
\text { et } a l^{17} \text { (PACES) }\end{array}$ & Sildenafil & 267 & $55(21)$ & $\mathrm{RCT}, \mathrm{DB}$ & $\begin{array}{l}20 \mathrm{mg} \times 3 / \text { day, titrated to } 40 \mathrm{mg} \\
\text { and } 80 \mathrm{mg} \times 3 / \text { day, as tolerated, at } \\
\text { 4-week intervals on background } \\
\text { treatment with epoprostenol }\end{array}$ & $\begin{array}{l}\text { Placebo on } \\
\text { background treatment } \\
\text { with epoprostenol }\end{array}$ & 16 & None \\
\hline $\begin{array}{l}\text { Galiè et al }{ }^{18} \\
\text { (PHIRST) }\end{array}$ & Tadalafil & 405 & $95(24)$ & $\mathrm{RCT}$, DB & $2.5,10,20$ and $40 \mathrm{mg}$ & Placebo & 16 & $\begin{array}{l}\text { Available in } \\
\text { this article }\end{array}$ \\
\hline Channick et al ${ }^{19}$ & Bosentan & 32 & $5(16)$ & $\mathrm{RCT}, \mathrm{DB}$ & $\begin{array}{l}62.5 \mathrm{mg} \times 2 / \text { day for } 4 \text { weeks, then } \\
125 \mathrm{mg} \times 2 / \text { day }\end{array}$ & Placebo & 12 & $\begin{array}{l}\text { Available in } \\
\text { Denton et al. } \\
(2006)^{35}\end{array}$ \\
\hline $\begin{array}{l}\text { Rubin et } a P^{0} \\
\text { (BREATHE-1) }\end{array}$ & Bosentan & 213 & $63(30)$ & $\mathrm{RCT}, \mathrm{DB}$ & $\begin{array}{l}62.5 \mathrm{mg} \times 2 / \text { day for } 4 \text { weeks, then } \\
125 \mathrm{mg} \text { or } 250 \mathrm{mg} \times 2 / \text { day }\end{array}$ & Placebo & 16 & $\begin{array}{l}\text { Available in } \\
\text { Denton et } a l^{\beta 5}\end{array}$ \\
\hline $\begin{array}{l}\text { Galiè et } a^{21} \\
\text { (BREATHE-5) }\end{array}$ & Bosentan & 54 & 0 & $\mathrm{RCT}, \mathrm{DB}$ & $\begin{array}{l}62.5 \mathrm{mg} \times 2 / \text { day for } 4 \text { weeks, then } \\
125 \mathrm{mg} \times 2 / \text { day }\end{array}$ & Placebo & 16 & None \\
\hline $\begin{array}{l}\text { Galiè et } a R^{2} \\
\text { (EARLY) }\end{array}$ & Bosentan & 185 & $33(18)$ & $\mathrm{RCT}, \mathrm{DB}$ & $\begin{array}{l}62.5 \mathrm{mg} \times 2 / \text { day for } 4 \text { weeks, then } \\
125 \mathrm{mg} \times 2 / \text { day }\end{array}$ & Placebo & 24 & None \\
\hline $\begin{array}{l}\text { Galiè et } a^{23} \\
\text { (ARIES) }\end{array}$ & Ambrisentan & 393 & $124(32)$ & $\mathrm{RCT}, \mathrm{DB}$ & $2.5,5$ and $10 \mathrm{mg}$ & Placebo & 12 & $\begin{array}{l}\text { Available in } \\
\text { Badesch }^{37}\end{array}$ \\
\hline Rubin et $a P^{4}$ & Epoprostenol & 23 & 0 & $\begin{array}{l}\text { RCT, } \\
\text { open-label }\end{array}$ & $\begin{array}{l}\text { Initial dosage of } 1-2 \mathrm{ng} / \mathrm{kg} / \mathrm{min} \text {, } \\
\text { then titrated to an optimal dose }\end{array}$ & Conventional therapy & 8 & None \\
\hline Barst et $a^{25}$ & Epoprostenol & 81 & 0 & $\begin{array}{l}\text { RCT, } \\
\text { open-label }\end{array}$ & $\begin{array}{l}\text { Initial dosage of } 2 \mathrm{ng} / \mathrm{kg} / \mathrm{min} \text {, then } \\
\text { titrated to optimal dosage }\end{array}$ & Conventional therapy & 12 & None \\
\hline Badesch et $a^{26}$ & Epoprostenol & 111 & $111(100)$ & $\begin{array}{l}\text { RCT, } \\
\text { open-label }\end{array}$ & $\begin{array}{l}\text { Dosage established according to } \\
\text { signs and symptoms from an } \\
\text { initial low dose }\end{array}$ & Conventional therapy & 12 & $\begin{array}{l}\text { Available in } \\
\text { this article }\end{array}$ \\
\hline $\begin{array}{l}\text { Galiè et } a p^{7} \\
\text { (ALPHABET) }\end{array}$ & Beraprost & 130 & $13(10)$ & $\mathrm{RCT}, \mathrm{DB}$ & $\begin{array}{l}20 \mathrm{mg} \times 4 / \text { day for first week, then } \\
\text { titrated to } 120 \mathrm{mg} \times 4 / \text { day }\end{array}$ & Placebo & 12 & None \\
\hline $\begin{array}{l}\text { McLaughlin } \\
\text { et } a R^{88} \text { (STEP) }\end{array}$ & $\begin{array}{l}\text { Inhaled } \\
\text { iloprost }\end{array}$ & 67 & NR & $\mathrm{RCT}, \mathrm{DB}$ & $\begin{array}{l}5 \mathrm{mg} \text { on background treatment } \\
\text { with bosentan ( } 125 \mathrm{mg} \times 2 / \text { day })\end{array}$ & $\begin{array}{l}\text { Placebo on } \\
\text { background treatment } \\
\text { with bosentan } \\
(125 \mathrm{mg} \times 2 / \text { day })\end{array}$ & 12 & None \\
\hline $\begin{array}{l}\text { Hoeper et a }{ }^{99} \\
\text { (COMBI) }\end{array}$ & $\begin{array}{l}\text { Inhaled } \\
\text { iloprost }\end{array}$ & 40 & 0 & $\begin{array}{l}\text { RCT, } \\
\text { open-label }\end{array}$ & $\begin{array}{l}5 \mathrm{mg} \text { on background treatment } \\
\text { with bosentan }(125 \mathrm{mg} \times 2 / \text { day })\end{array}$ & $\begin{array}{l}\text { Placebo on } \\
\text { background treatment }\end{array}$ & 12 & None \\
\hline
\end{tabular}




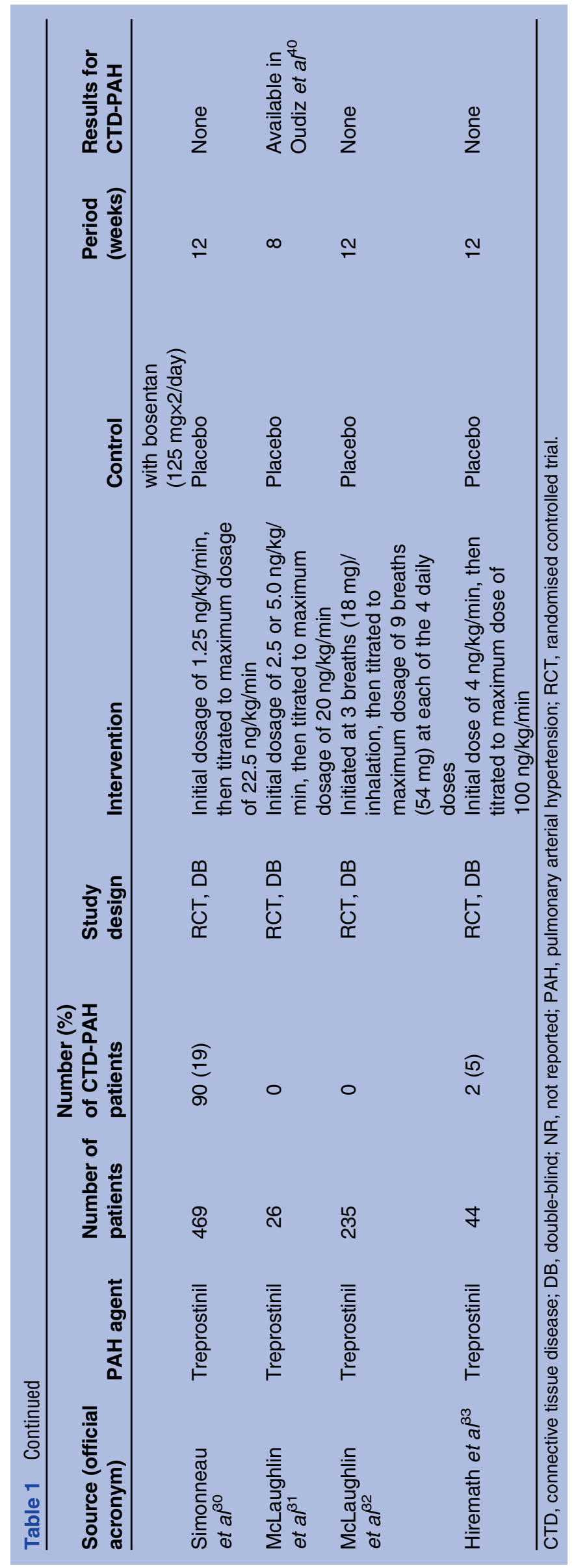

beraprost and treprostinil), no obvious trends were found between patient groups.

\section{Risk of bias}

We rated risk of bias for each study (full data in online supplementary table S3). In studies for all forms of PAH, none were at high risk of bias for random sequence generation or allocation concealment; however, the method of randomisation and allocation concealment were unclear (ie, not reported) for 11 and 9 studies, respectively. Four studies were at high risk of bias for blinding because they were open-label studies. Three studies were at high risk for another source of bias (imbalance in missing data between groups, ${ }^{17}$ imbalance in baseline $6 \mathrm{MWD}^{25}$ and early termination based on futility analysis ${ }^{29}$ ).

Of studies for CTD-PAH, three studies were at high risk of bias with respect to all domains because they were open-label, single-arm studies. ${ }^{36} 38{ }^{39}$ One study was at high risk of bias resulting from imbalance in baseline characteristics. ${ }^{35}$ The remaining studies were judged to be not of high risk of bias in any of the domains.

\section{DISCUSSION}

A finding of the present meta-analysis of 19 studies is that in combined patients with all forms of $\mathrm{PAH}$, all agents increase 6 MWD compared with the control group. ${ }^{15-33}$ Likewise, the meta-analysis of nine studies on patients with CTD-PAH also showed an increase in 6 MWD by all agents. ${ }^{18} 26$ 34-40 The finding that all agents increase 6 MWD in all patients with PAH is consistent with the results of the five previous systematic reviews and meta-analyses that evaluated the three types of agent (PDE-5 inhibitors, ERAs and $\mathrm{PGI}_{2}$ analogues). ${ }^{9-13}$ To date, reports of meta-analyses that included patients with CTD-PAH including SSc-PAH are limited to one study that evaluated three oral agents (sildenafil, bosentan and sitaxsentan) alone. ${ }^{8}$ The findings of this meta-analysis are important because patients with all PAH as well as a subgroup of patients with CTD-PAH were included, and the effects of three types of agent, including intravenous preparations, were thoroughly evaluated. Our meta-analysis shows similar trends to the findings of Avouac et al. ${ }^{8}$

When the mean differences between changes in 6 MWD were compared between all patients with PAH and patients with CTD-PAH, the effects of ERAs (bosen$\tan$ and ambrisentan) on exercise tolerance may be less in patients with CTD-PAH, whereas no difference in exercise capacity was found between patient groups for PDE-5 inhibitors and $\mathrm{PGI}_{2}$ analogues. This result should be interpreted cautiously because recent data from registries have shown that $6 \mathrm{MWD}$ is significantly lower in patients with CTD-PAH than in those with idiopathic $\mathrm{PAH}^{4}{ }^{41}$ and a systematic review has shown that 6 MWD may be only partially valid in patients with SSc-PAH. ${ }^{42}$

This analysis has several limitations. First, we could identify only a limited number of studies for some agents (one study each for tadalafil, ambrisentan and 


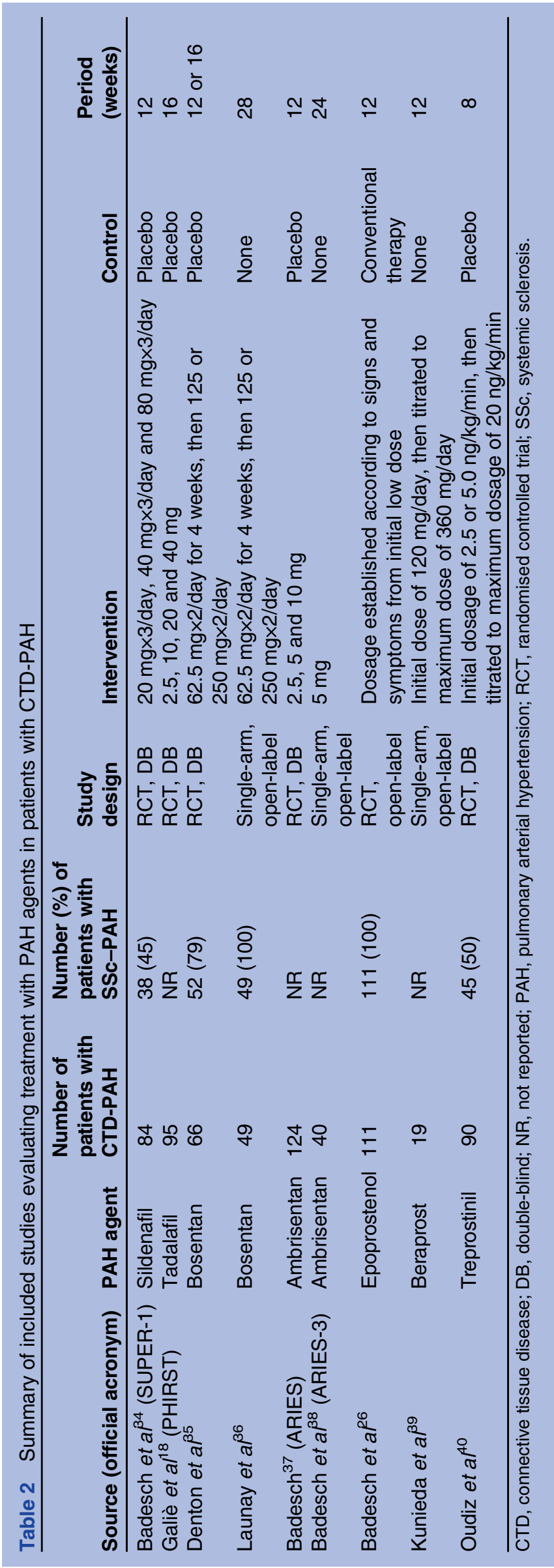

beraprost), and studies that included a subgroup of patients with CTD-PAH including SSc-PAH were scarce. Second, ideally data for patients with CTD-PAH should be compared with those for patients with other forms of PAH. However, there were insufficient data for forms of PAH other than CTD-PAH, so this analysis compared data for all PAH and CTD-PAH. Third, the study designs varied: some studies that included patients with CTD-PAH were performed in an open-label or singlearm, open-label manner, some having a short observation period ( 8 or 12 weeks) or using combination therapy. Of note, in studies of combination therapy, changes in 6 MWD are expected to be smaller, because patients are already receiving PAH therapy at the start of the study. Patient background characteristics were also inconsistent between studies: patients were in various WHO FC classes and had various baseline $6 \mathrm{MWD}$ values, which can influence the effects of each agent, and some articles reported no such information. Moreover, the percentage of patients with SSc-PAH in the study population also varied, which is a study limitation because there is a difference in treatment response between patients with SSc and non-SSc and patients with SSc-PAH have poor prognosis compared with patients with other CTD-PAH. ${ }^{4}$ In this meta-analysis, the percentages of patients with SSc-PAH were as follows: for sildenafil, $45 \%$ in the study by Badesch $e t a P^{34}$; for bosen$\tan , 79 \%$ in the study by Denton $e t a l^{35}$; and $100 \%$ in the study by Launay et $a l^{36}$; and for epoprostenol, $100 \%$ in the study by Badesch et al. ${ }^{26}$ The percentage was unknown in the study of tadalafil by Galiè $e t a l^{18}$; in those of ambrisentan by Badesch et $a l^{37} 38$; and in that of beraprost by Kunieda et al. ${ }^{39}$ Patients with SSc-PAH were more frequently enrolled in studies for bosentan ${ }^{35} 36$ than in the sildenafil study. ${ }^{34}$

It would have been interesting to do a sensitivity analysis with the data from patients with SSc-PAH only, but this is not possible for the following reasons. There are only two articles (Launay et $a l^{36}$ and Badesch et $a l^{26}$ ) from which data for the subpopulation of patients with SSc-PAH can be extracted. Another limitation of our study was the inclusion of data for non-approved, possibly subtherapeutic doses, which may have reduced the effects of the PAH agents in some studies. Finally, there may be publication bias, so negative results are likely to be unpublished. ${ }^{43}$

Furthermore, the present analysis is intended to compare changes in $6 \mathrm{MWD}$ over a short period of time, therefore whether the results are associated with patient survival remains unclear. However, 6 MWD is effective as an indicator of the severity of $\mathrm{PAH}^{44}$ Moreover, an ongoing large-scale registry, the US Registry to Evaluate Early and Long-Term PAH Disease Management (REVEAL), which aims to clarify the characteristics and prognosis of patients with $\mathrm{PAH}$ and the latest treatment for PAH, has shown that 6 MWD is an independent predictor that is significantly associated with 1-year survival. ${ }^{45}$ Several other studies have also confirmed its role as an 
PDE-5 inhibitors

Sildenafil

Galiè et al. $(2005)^{15} 20 \mathrm{mg}$

Galiè et al. (2005) $40 \mathrm{mg}$

Galiè et al. (2005) $)^{15} 80 \mathrm{mg}$

Singh et al. $(2006)^{16}$

Simonneau et al. $(2008)^{17}$

Subtotal

Heterogeneity: $F=50.1 \%$

Tadalafil

Galiè et al. (2009) ${ }^{18} 2.5 \mathrm{mg}$

Galiè et al. (2009) ${ }^{18} 10 \mathrm{mg}$

Galiè et al. $(2009)^{18} 20 \mathrm{mg}$

Galiè et al. (2009) ${ }^{18} 40 \mathrm{mg}$

Subtotal

Heterogeneity: $P^{2}=7.9 \%$

\section{ERAs}

Bosentan

Channick et al. (2001)

Rubin et al. $(2002)^{20}$

Galiè et al. $(2006)^{21}$

Galiè et al. (2008) 22

Subtotal

Heterogeneity: $F^{2}=38.3 \%$

Ambrisentan

Galiè et al. (2008) $23.5 \mathrm{mg}$

Galiè et al. $(2008)^{23} 5 \mathrm{mg}$

Galiè et al. $(2008)^{23} 10 \mathrm{mg}$

Subtotal

Heterogeneity: $\hat{P}^{2}=0 \%$

$\mathrm{PGI}_{2}$ analogues

Epoprostenol

Rubin et al. $(1990)^{24}$

Barst et al. (1996) 25

Badesch et al. $(2000)^{26}$

Subtotal

Heterogeneity: $F^{2}=43.3 \%$

Beraprost

Galiè et al. $(2002)^{27}$

Subtotal

Heterogeneity: $r^{2}=N A$

Inhaled iloprost

McLaughlin et al. (2006) ${ }^{28}$

Hoeper et al. (2006) ${ }^{29}$

Subtotal

Heterogeneity: $l^{2}=39.7 \%$

Treprostinil

Simonneau et al. $(2002)^{30}$

McLaughlin et al. $(2003)^{3 !}$

McLaughlin et al. $(2010)^{32}$

Hiremath et al. (2010)

Subtotal

Heterogeneity: $F=29.4 \%$

Total

Heterogeneity: $l^{2}=63.2 \%$

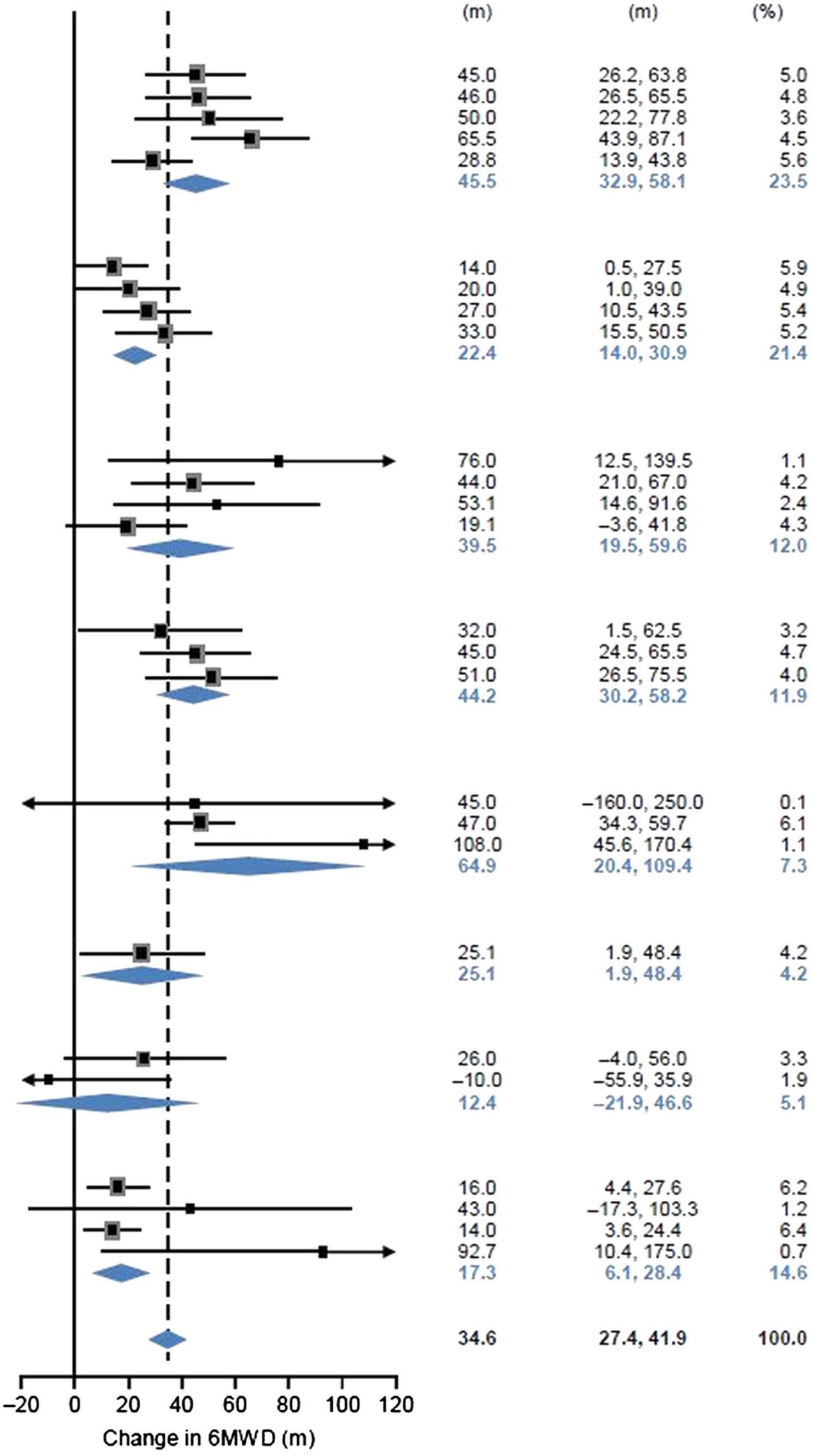

Figure 2 Effects of individual pulmonary arterial hypertension (PAH) agents on 6 min walk distance (6 MWD) in patients with any form of PAH. ERA, endothelin receptor antagonist; NA, not applicable; PDE, phosphodiesterase; $\mathrm{PGI}_{2}$, prostacyclin. 


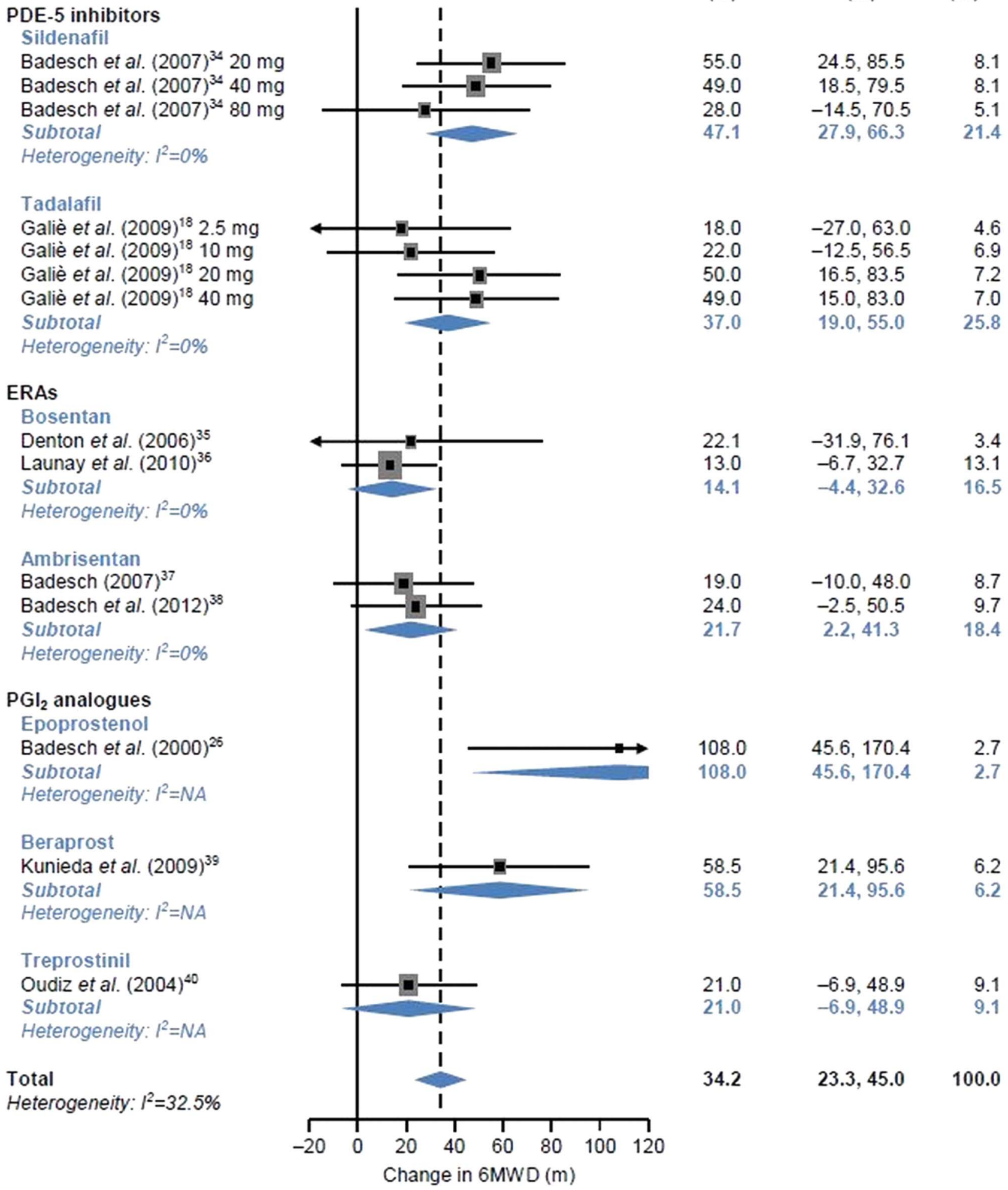

Figure 3 Effects of individual pulmonary arterial hypertension (PAH) agents on 6 min walk distance (6 MWD) in patients with PAH associated with connective tissue disease. ERA, endothelin receptor antagonist; NA, not applicable; PDE, phosphodiesterase; $\mathrm{PGl}_{2}$, prostacyclin. For single-arm studies, the mean changes from baseline are shown.

independent predictor of prognosis. ${ }^{46-50}$ In addition, investigators who did a placebo-controlled randomised trial of the PDE-5 inhibitor sildenafil have recently identified the minimum clinically meaningful changes in $6 \mathrm{MWD}$, and concluded that it would be a useful indicator to determine the efficacy of other PAH agents. ${ }^{51}$ 
However, pharmacological treatment for PAH is shifting from monotherapy to combination therapy, and it is expected that clinical studies investigating the efficacy of combination therapy will increase. Therefore, it will be increasingly difficult to do a meta-analysis that includes all the new studies to detect differences between PAH agents. The present analysis is meaningful because it included all available clinical study results to date, and we hope that it contributes to the improvement of the treatment for PAH.

In conclusion, the present meta-analysis of studies that included patients with CTD-PAH showed an increase in 6 MWD by all agents, that is, PDE- 5 inhibitors, ERAs and $\mathrm{PGI}_{2}$ analogues. Comparison of the mean differences between changes in 6 MWD suggest that, for bosentan and ambrisentan, the effects on exercise tolerance may differ depending on patient group, whereas the PDE-5 inhibitors sildenafil and tadalafil and the $\mathrm{PGI}_{2}$ analogue epoprostenol show consistent effects regardless of the presence or absence of CTD. Further studies are needed to clarify the clinical implications of these findings.

Contributors NM collected the data and performed the statistical analyses described in this article. NS reviewed the collection and analyses of the data. He helped conceive and design the meta-analysis, interpret the results and revise the manuscript. MK is directly responsible for the manuscript. He reviewed the data analyses and drafted the manuscript, providing important intellectual content from the perspective of a CTD-PAH specialist. HW revised the manuscript critically for important intellectual content from the perspective of a PAH specialist. All authors have read and approved the final version of the manuscript.

Funding This research received no specific grant from any funding agency in the public, commercial or not-for-profit sectors.

Competing interests MK has received research funding from Actelion Pharmaceuticals, GlaxoSmithKline, Novartis and Pfizer, and lecture fees from Actelion Pharmaceuticals, Pfizer, GlaxoSmithKline, Nippon Shinyaku, Mitsubishi Tanabe Pharma and Takeda Pharmaceuticals. WH has received research funding from the Ministry of Health, Labour and Welfare of Japan, Teika Seiyaku, Takeda Pharmaceuticals, Mochida, Pfizer, Asteras and Daiichi Sankyo, and lecture fees from Pfizer, Acterion, Novartis, Daiich Sankyo, GlaxoSmithKline and Nihon Shinyaku. NM and NS are employees of Pfizer Japan Inc.

Provenance and peer review Not commissioned; externally peer reviewed.

Data sharing statement No additional data are available.

Open Access This is an Open Access article distributed in accordance with the Creative Commons Attribution Non Commercial (CC BY-NC 3.0) license, which permits others to distribute, remix, adapt, build upon this work noncommercially, and license their derivative works on different terms, provided the original work is properly cited and the use is non-commercial. See: http:// creativecommons.org/licenses/by-nc/3.0/

\section{REFERENCES}

1. Badesch DB, Champion HC, Sanchez MA, et al. Diagnosis and assessment of pulmonary arterial hypertension. J Am Coll Cardiol 2009:54:S55-66.

2. Simonneau G, Robbins IM, Beghetti M, et al. Updated clinical classification of pulmonary hypertension. J Am Coll Cardiol 2009;54 S43-54.

3. Condliffe R, Kiely DG, Peacock AJ, et al. Connective tissue disease-associated pulmonary hypertension in the modern treatment era. Am J Respir Crit Care Med 2009;179:151-7.

4. Chung L, Liu J, Parsons L, et al. Characterization of connective tissue disease-associated pulmonary arterial hypertension from REVEAL: identifying systemic sclerosis as a unique phenotype. Chest 2010;138:1383-94.
5. Hachulla E, Gressin V, Guilevin L, et al. Early detection of pulmonary arterial hypertension in systemic sclerosis: a French nationwide prospective multicenter study. Arthritis Rheum 2005;52:3792-800.

6. Mukerjee D, St George D, Coleiro B, et al. Prevalence and outcome in systemic sclerosis associated pulmonary arterial hypertension: application of a registry approach. Ann Rheum Dis 2003;62:1088-93.

7. Kawut SM, Taichman DB, Archer-Chicko CL, et al. Hemodynamics and survival in patients with pulmonary arterial hypertension related to systemic sclerosis. Chest 2003;123:344-50.

8. Avouac J, Wipff J, Kahan A, et al. Effects of oral treatments on exercise capacity in systemic sclerosis related pulmonary arterial hypertension: a meta-analysis of randomised controlled trials. Ann Rheum Dis 2008;67:808-14.

9. Galiè N, Manes A, Negro L, et al. A meta-analysis of randomized controlled trials in pulmonary arterial hypertension. Eur Heart $J$ 2009;30:394-403.

10. Galiè N, Palazzini M, Manes A. Pulmonary arterial hypertension: from the kingdom of the near-dead to multiple clinical trial meta-analyses. Eur Heart J 2010;31:2080-6.

11. Macchia A, Marchioli R, Tognoni G, et al. Systematic review of trials using vasodilators in pulmonary arterial hypertension: why a new approach is needed. Am Heart $J$ 2010;159:245-57.

12. He B, Zhang F, Li X, et al. Meta-analysis of randomized controlled trials on treatment of pulmonary arterial hypertension. Circ $J$ 2010;74:1458-64

13. Ryerson CJ, Nayar S, Swiston JR, et al. Pharmacotherapy in pulmonary arterial hypertension: a systematic review and meta-analysis. Respir Res 2010;11:12.

14. McLaughlin VV, Badesch DB, Delcroix M, et al. End points and clinical trial design in pulmonary arterial hypertension. J Am Coll Cardiol 2009;54:S97-107.

15. Galiè N, Ghofrani HA, Torbicki A, et al. Sildenafil citrate therapy for pulmonary arterial hypertension. N Engl J Med 2005;353:2148-57.

16. Singh TP, Rohit M, Grover A, et al. A randomized, placebo-controlled, double-blind, crossover study to evaluate the efficacy of oral sildenafil therapy in severe pulmonary artery hypertension. Am Heart J 2006;151:851.e1-5.

17. Simonneau G, Rubin LJ, Galiè N, et al. Addition of sildenafil to long-term intravenous epoprostenol therapy in patients with pulmonary arterial hypertension: a randomized trial. Ann Intern Med 2008;149:521-30.

18. Galiè N, Brundage $\mathrm{BH}$, Ghofrani HA, et al. Tadalafil therapy for pulmonary arterial hypertension. Circulation 2009;119:2894-903.

19. Channick RN, Simonneau G, Sitbon O, et al. Effects of the dual endothelin-receptor antagonist bosentan in patients with pulmonary hypertension: a randomised placebo-controlled study. Lancet 2001;358:1119-23.

20. Rubin LJ, Badesch DB, Barst RJ, et al. Bosentan therapy for pulmonary arterial hypertension. N Engl J Med 2002;346:896-903.

21. Galiè N, Beghetti M, Gatzoulis MA, et al. Bosentan therapy in patients with Eisenmenger syndrome: a multicenter, double-blind, randomized, placebo-controlled study. Circulation 2006;114:48-54.

22. Galiè N, Rubin LJ, Hoeper M, et al. Treatment of patients with mildly symptomatic pulmonary arterial hypertension with bosentan (EARLY study): a double-blind, randomised controlled trial. Lancet 2008;371:2093-100.

23. Galiè N, Olschewski H, Oudiz RJ, et al. Ambrisentan for the treatment of pulmonary arterial hypertension: results of the ambrisentan in pulmonary arterial hypertension, randomized, double-blind, placebo-controlled, multicenter, efficacy (ARIES) study 1 and 2. Circulation 2008;117:3010-19.

24. Rubin LJ, Mendoza J, Hood M, et al. Treatment of primary pulmonary hypertension with continuous intravenous prostacyclin (epoprostenol). Results of a randomized trial. Ann Intern Med 1990;112:485-91.

25. Barst RJ, Rubin LJ, Long WA, et al. A comparison of continuous intravenous epoprostenol (prostacyclin) with conventional therapy for primary pulmonary hypertension. The Primary Pulmonary Hypertension Study Group. N Engl J Med 1996;334:296-302.

26. Badesch DB, Tapson VF, McGoon MD, et al. Continuous intravenous epoprostenol for pulmonary hypertension due to the scleroderma spectrum of disease. A randomized, controlled trial. Ann Intern Med 2000;132:425-34.

27. Galiè N, Humbert M, Vachiéry JL, et al. Effects of beraprost sodium, an oral prostacyclin analogue, in patients with pulmonary arterial hypertension: a randomized, double-blind, placebo-controlled trial. J Am Coll Cardiol 2002;39:1496-502.

28. McLaughlin VV, Oudiz RJ, Frost A, et al. Randomized study of adding inhaled iloprost to existing bosentan in pulmonary arterial hypertension. Am J Respir Crit Care Med 2006;174:1257-63. 
29. Hoeper MM, Leuchte $\mathrm{H}$, Halank M, et al. Combining inhaled iloprost with bosentan in patients with idiopathic pulmonary arterial hypertension. Eur Respir J 2006;28:691-4.

30. Simonneau G, Barst RJ, Galiè N, et al. Continuous subcutaneous infusion of treprostinil, a prostacyclin analogue, in patients with pulmonary arterial hypertension: a double-blind, randomized, placebo-controlled trial. Am J Respir Crit Care Med 2002 165:800-4.

31. McLaughlin VV, Gaine SP, Barst RJ, et al. Efficacy and safety of treprostinil: an epoprostenol analog for primary pulmonary hypertension. J Cardiovasc Pharmacol 2003;41:293-9.

32. McLaughlin VV, Benza RL, Rubin LJ, et al. Addition of inhaled treprostinil to oral therapy for pulmonary arterial hypertension. $J A m$ Coll Cardiol 2010;55:1915-22.

33. Hiremath J, Thanikachalam S, Parikh K, et al. Exercise improvement and plasma biomarker changes with intravenous treprostinil therapy for pulmonary arterial hypertension: a placebo-controlled trial. $J$ Heart Lung Transplant 2010;29:137-49.

34. Badesch DB, Hill NS, Burgess G, et al. Sildenafil for pulmonary arterial hypertension associated with connective tissue disease. $J$ Rheumatol 2007;34:2417-22.

35. Denton CP, Humbert M, Rubin L, et al. Bosentan treatment for pulmonary arterial hypertension related to connective tissue disease: a subgroup analysis of the pivotal clinical trials and their open-label extensions. Ann Rheum Dis 2006;65:1336-40.

36. Launay D, Sitbon O, Le Pavec J, et al. Long-term outcome of systemic sclerosis-associated pulmonary arterial hypertension treated with bosentan as first-line monotherapy followed or not by the addition of prostanoids or sildenafil. Rheumatology 2010;49:490-500.

37. Badesch DB. Ambrisentan therapy for pulmonary arterial hypertension: a comparison by $\mathrm{PAH}$ etiology. Chest 2007; 132(Meeting Abstract):488b-489.

38. Badesch DB, Feldman J, Keogh A, et al. ARIES-3: ambrisentan therapy in a diverse population of patients with pulmonary hypertension. Cardiovasc Ther 2012;30:93-9.

39. Kunieda T, Nakanishi N, Matsubara $\mathrm{H}$, et al. Effects of long-acting beraprost sodium (TRK-100STP) in Japanese patients with pulmonary arterial hypertension. Int Heart $J$ 2009;50:513-29.
40. Oudiz R, Schilz RJ, Barst RJ, et al. Treprostinil, a prostacyclin analogue, in pulmonary arterial hypertension associated with connective tissue disease. Chest 2004;126:420-7.

41. Clements PJ, Tan M, McLaughlin VV, et al. The pulmonary arterial hypertension quality enhancement research initiative: comparison of patients with idiopathic $\mathrm{PAH}$ to patients with systemic sclerosis-associated PAH. Ann Rheum Dis 2012;71:249-52.

42. Avouac J, Kowal-Bielecka O, Pittrow D, et al.; EPOSS Group. Validation of the 6 min walk test according to the OMERACT filter: a systematic literature review by the EPOSS-OMERACT group. Ann Rheum Dis 2010;69:1360-3.

43. Ahmed I, Sutton AJ, Riley RD. Assessment of publication bias, selection bias, and unavailable data in meta-analyses using individual participant data: a database survey. BMJ 2012;344:d7762.

44. Naeije R. The 6-min walk distance in pulmonary arterial hypertension: "Je t'aime, moi non plus". Chest 2010;137:1258-60.

45. Benza RL, Miller DP, Gomberg-Maitland M, et al. Predicting survival in pulmonary arterial hypertension: insights from the Registry to Evaluate Early and Long-Term Pulmonary Arterial Hypertension Disease Management (REVEAL). Circulation 2010;122:164-72.

46. Miyamoto $\mathrm{S}$, Nagaya N, Satoh T, et al. Clinical correlates and prognostic significance of six-minute walk test in patients with primary pulmonary hypertension. Comparison with cardiopulmonary exercise testing. Am J Respir Crit Care Med 2000;161:487-92.

47. Sitbon $\mathrm{O}$, Humbert $\mathrm{M}$, Nunes $\mathrm{H}$, et al. Long-term intravenous epoprostenol infusion in primary pulmonary hypertension: prognostic factors and survival. J Am Coll Cardiol 2002;40:780-8.

48. Groepenhoff $\mathrm{H}$, Vonk-Noordegraaf A, Boonstra A, et al. Exercise testing to estimate survival in pulmonary hypertension. Med Sci Sports Exerc 2008;40:1725-32.

49. Humbert $M$, Sitbon $O$, Chaouat $A$, et al. Survival in patients with idiopathic, familial, and anorexigen-associated pulmonary arterial hypertension in the modern management era. Circulation 2010;122:156-63.

50. Humbert M, Sitbon O, Yaïci A, et al. Survival in incident and prevalent cohorts of patients with pulmonary arterial hypertension. Eur Respir J 2010;36:549-55.

51. Gilbert C, Brown MC, Cappelleri JC, et al. Estimating a minimally important difference in pulmonary arterial hypertension following treatment with sildenafil. Chest 2009;135:137-42. 